\title{
Stress reduction strategies in breast cancer: review of pharmacologic and non-pharmacologic based strategies
}

\author{
Rohit Gosain $^{1,2}$ - Elizabeth Gage-Bouchard ${ }^{3}$. Christine Ambrosone ${ }^{3}$ - Elizabeth Repasky ${ }^{4} \cdot$ Shipra Gandhi $^{1}$
}

Received: 30 March 2020 / Accepted: 30 July 2020 / Published online: 18 September 2020

(C) The Author(s) 2020

\begin{abstract}
Breast cancer is the most common cancer diagnosed in women. It is associated with multiple symptoms in both patients and caregivers, such as stress, anxiety, depression, sleep disturbance, and fatigue. Stress appears to promote cancer progression via activation of the sympathetic nervous system releasing epinephrine and norepinephrine as well as activation of hypothalamicpituitary-adrenal axis releasing cortisol. These stress hormones have been shown to promote the proliferation of cancer cells. This review focuses on stress-reducing strategies which may decrease cancer progression by abrogating these pathways, with a main focus on the $\beta$-adrenergic signaling pathway. Patients utilize both non-pharmacologic and pharmacologic strategies to reduce stress. Non-pharmacologic stress-reduction strategies include complementary and alternative medicine techniques, such as meditation, yoga, acupuncture, exercise, use of natural products, support groups and psychology counseling, herbal compounds, and multivitamins. Pharmacologic strategies include abrogating the $\beta 2$-adrenergic receptor signaling pathway to antagonize epinephrine and norepinephrine action on tumor and immune cells. $\beta$-Blocker drugs may play a role in weakening the promigratory and pro-metastatic effects induced by stress hormones in cancer and strengthening the anti-tumor immune response. Preclinical models have shown that non-selective $\beta 1 / 2$-blocker use is associated with a decrease in tumor growth and metastases and clinical studies have suggested their positive impact on decreasing breast cancer recurrence and mortality. Thus, nonpharmacological approaches, along with pharmacological therapies part of clinical trials are available to cancer patients to reduce stress, and have promise to break the cycle of cancer and stress.
\end{abstract}

Keywords Breast cancer - Stress · Complementary and alternative medicine $~ \beta$-Blocker $\cdot$ Yoga $\cdot$ Pharmacological · Non-pharmacological strategies $\cdot$ Fatigue $\cdot$ Anxiety $\cdot$ Quality of life

This article is a contribution to the special issue on: Neuro-immune Interactions - Guest Editor: David Farrar

Rohit Gosain

rohit25@gmail.com

1 Department of Medicine, Roswell Park Comprehensive Cancer Center, Buffalo, NY, USA

2 Department of Medicine, UPMC Hillman Cancer Center, Chautauqua, NY, USA

3 Department of Cancer Prevention and Control, Roswell Park Comprehensive Cancer Center, Buffalo, NY, USA

4 Department of Immunology, Roswell Park Comprehensive Cancer Center, Buffalo, NY, USA

\section{Introduction}

Despite advancements in the field of cancer, from diagnosis and treatment standpoints, breast cancer remains a major health concern [1]. Stress appears to be an important factor affecting the quality of life of both patients and their caregivers. This review sheds light on how stress perceived by patients when they are diagnosed with cancer plays a role in cancer progression. Additionally, this review also highlights important research being conducted on non-pharmacological and pharmacological strategies for stress reduction in breast cancer patients. Breast cancer affects approximately $12 \%$ women in the USA during their lifetime [2]. The incidence rate for breast cancer is increasing globally, with 1.38 million new cases diagnosed in 2008, to about 1.7 million reported in 2012 [3-5] and 2.1 million cases in 2018 [6]. A significant proportion of this rise in incidence is attributed to changes in environmental and lifestyle factors [7]. 
Breast cancer is associated with symptoms which are physical, psychological, and cognitive [8]. The psychological consequences from breast cancer diagnosis include stress, anxiety, depression, and impaired cognitive function [9-12]. Physical symptoms that impact breast cancer patients range from pain, sleep disturbances, to fatigue [13-15]. Fatigue, which results in lack of energy, affects $40-80 \%$ of patients during and after treatment [16]. These symptoms which impact patients, such as fatigue, anxiety, and depression remain and/or occur years after the treatment, which significantly diminish quality of life and contribute to stress $[17,18]$.

A breast cancer diagnosis can also have profound consequences for patients' caregivers. Informal cancer caregivers are defined by NCI as individuals (commonly family members) who provide cancer care or other supportive activities that is typically uncompensated and provided at home [19]. Being a caregiver to a cancer patient can include multiple role demands and stressors [20]. Caregivers can experience even more distress, anxiety, and depressive symptoms than cancer patients, and over half of all cancer caregivers experience clinically significant distress [21, 22]. Caregivers with greater psychological stress are more likely to binge drink, smoke, avoid exercise, and feel physically unwell, have lower self-rated health and experience health declines and impaired immune function [22-25]. Caregivers with higher stress experience more difficulty executing caregiving tasks [19, 23, 26, 27]. At the same time, caregivers with a lower stress management ability report less preparedness and decision-making efficacy [28]. Recent research has begun to examine how the physical and mental health outcomes of patients and caregivers are related; increased caregiver stress is associated with lower patient perceived quality of cancer care [23, 27, 29]. There are dyadic relationships between stress experiences among breast cancer patients and their caregivers. For example, increased caregiver stress is associated with patient depression and anxiety [30].

To deal with these symptoms, patients and their caregivers often explore different coping mechanisms, ranging from nonpharmacologic means like meditation, yoga, and exercise to pharmacologic modalities. This review focuses on use of these modalities among breast cancer patients to manage stress associated with their cancer diagnosis. A total of 48 to $80 \%$ of American women diagnosed with breast cancer make use of complementary therapies, while worldwide it ranges from 33 to $47 \%$ [31]. For example, meditation is one complementary modality which helps patients cope with pain, stress, depression and adverse effects [32, 33]. Meditation has also been shown to improve sleep quality, feelings of empowerment, competence, personal growth, sense of calm, serenity, and balance $[15,34]$. In addition to non-pharmacological remedies, pharmacological agents have also been used. The human body's natural reaction to acute psychosocial stress includes "fight or flight" response, resulting in activation of sympathetic nervous system [35]. Norepinephrine (NE) as a driver of the sympathetic response has been examined as a possible contributor to cancer progression [36-38]. $\beta$-Adrenergic receptors have been shown to be responsible for cancer development, progression, and angiogenesis [39, 40]. Multiple preclinical studies in various cancers have documented that $\beta$ blockers can arrest the stress-induced catecholamine release of epinephrine and NE, resulting in suppression of pro-growth and pro-angiogenic effects [41-44] and improve anti-tumor immunity [45-48].

The diagnosis of cancer can be associated with physical and psychological stress in patients. Stress has been shown to promote cancer growth. As a result, to counter this stress response, patients utilize several non-pharmacological strategies. This review describes the mechanism of stress response in cancer, and additionally highlights the pharmacologic and non-phamacologic approaches utilized by cancer patients focusing on inhibiting the elevated stress-induced sympathetic nervous system. These approaches enhance quality of life and also help cope with stress which may result in better survival outcomes.

\section{Stress promotes cancer progression}

The term "stress" captures the psychophysiological processes a person may have in response to an event perceived to be harmful or challenging [49]. When focusing on physiologic responses to stress, it is important to understand the mechanism behind the stress response which may further promote cancer progression. Two branches of the nervous system are involved in stress response, the sympathetic nervous system (SNS), and the hypothalamic-pituitary-adrenal (HPA) axis. These pathways are activated when stress is perceived and result in release of several neurotransmitters and hormones that facilitate behavioral and biochemical changes thereafter [48]. In cancer patients, it is suspected that this dysregulation of the SNS and HPA axis is responsible for cancer progression [50].

HPA axis and cortisol in cancer cells The principal effectors of the stress response are located in the paraventricular nucleus (PVN) of the hypothalamus, the anterior lobe of the pituitary gland, and the adrenal gland. This collection of structures is referred to as the HPA axis. In response to stress, corticotropin-releasing factor (CRF) released from the hypothalamus acts on the pituitary gland to induce the release of adrenocorticotropic hormone (ACTH) into the systemic circulation. The principal target for circulating ACTH is the adrenal cortex, where it stimulates glucocorticoid synthesis and secretion from the zona fasciculata [51]. Glucocorticoids, such as 
dexamethasone, stimulate anti-apoptotic gene expression and antagonize the cell death mechanism resulting in progression of epithelial tumors [50]. Psychological stressors, acute or chronic, have been shown to disrupt the neuroendocrine circadian rhythm which may promote cancer growth [52]. This is exemplified in a study of patients with metastatic breast cancer where a hyperactive adrenal gland resulted in chronically elevated resting plasma cortisol levels, along with possible tamoxifen administration resulting in higher cortisol. Interestingly, a linear relationship was observed between cortisol levels and the cancer stage, where patients with metastatic breast cancer had significantly higher levels of basal cortisol compared to early stage breast cancer patients who had lower cortisol levels [53]. This increase in cortisol levels is concerning as it has been well documented that cortisol promotes cancer progression via direct activity on tumor cells by activating glucocorticoid receptor (GR) signaling pathway, and upregulating downstream anti-apoptotic genes such as serum/glucocorticoid-regulated kinase $1(S G K 1)$ and mitogen activated protein kinase phosphatase $1(M K P 1) /$ dual specificity phosphatase 1 (DUSP1) [54]. At the same time, cortisol suppresses immune function, with decreases in natural killer (NK) cell activity and T cell proliferation [55].

\section{Sympathetic innervation and epinephrine/norepinephrine re-} lease in cancer cells Release and function of catecholamines (norepinephrine and epinephrine) from the autonomic nervous system is best understood from the "fight-or-flight" response, also referred to as the acute stress response (physiological and psychological response from body in a stressful situation). This state of stress results in rapid heart rate and breathing, pale and flushed skin, dilated pupils, and trembling [56]. The adrenergic receptors, which are the target of epinephrine and norepinephrine, are responsible for regulating apoptosis, proliferation, and angiogenesis in normal tissues [48]. Adrenergic receptors are also expressed on various cancer cells, including breast, melanoma, pituitary, pancreatic, lung, melanoma and prostate cancer [57-63]. Studies have focused on neuroendocrine regulation of breast cancer progression via sympathetic nervous system with release of epinephrine and norepinephrine neurotransmitters [37, 38, 64-66]. Preclinical studies have further demonstrated that these neurotransmitters induce tumor cell invasion and migration aiding in metastasis [67-71]. Specifically in breast cancer, in vivo studies have demonstrated that adrenergic signaling has an association with increased nodal involvement and development of metastasis [72]. Kamiya et al. showed that breast cancer growth and progression can be stimulated with sympathetic nerve innervation in mice. Conversely, this growth can be suppressed with parasympathetic stimulation. Higher parasympathetic activity promotes energy conservation, while increased sympathetic activity depletes those energy stores [73]. This combination of elevated sympathetic nervous system activity along with parasympathetic underactivity has been associated with increased cancer related fatigue, activation of proinflammatory cytokine network, and an increased incidence of cancer recurrence in breast cancer [74-76].

In summary, stress promotes cancer progression via release of several hormones and neurotransmitters causing tumor cell progression and also inducing immune system dysfunction. To decrease stress, there are several non-pharmacological and pharmacological stress reduction strategies utilized by patients and their families.

\section{Non-pharmacological strategies to reduce stress}

There are many complementary and integrative therapies employed by patients and their families to reduce stress and promote better quality of life, which as highlighted above, may provide significant anti-cancer effects. The National Center for Complementary and Alternative Medicine (NCCAM) is an initiative by the National Institutes of Health (NIH), comprised of diverse heathcare systems and practices [77]. Some of the modalities (part of NCCAM) include mindbody medicine, nutritional supplementation, use of herbal products, exercises, and other energy-based techniques.

Millions of Americans use some form of CAM, and this number has been growing each year. According to a survey conducted in 2007, about 38\% of American adults and approximately $12 \%$ of American children used some form of CAM [78]. These numbers are significantly higher when focusing on breast cancer patients [79-83]. A European study, which included a total of 11 countries, reported $44.7 \%$ prevalence of CAM use in breast cancer patients [82]. Recent studies have demonstrated higher number of breast cancer patients using CAM to enhance their quality of life; with reports of $62.9 \%$ use in Germany, $81.9 \%$ in Canada, and $86.1 \%$ in the USA [79-81]. Among $86.1 \%$ patients in the US study who used CAM following breast cancer diagnosis, $47.5 \%$ used botanical supplements, $47.2 \%$ used other natural products, $28.8 \%$ used special diets, $64.2 \%$ used mind-body healing, and $26.5 \%$ used body/energy/ other treatments [81]. Other CAMs used by breast cancer patients include spiritual approaches, such as prayers, meditation, and mental healing [84]. Spiritual and religious practices, especially praying, has been one of the coping strategies used by breast cancer patients [85]. In addition, manipulative and body-based methods such as therapeutic massage in breast cancer patients shows beneficial effects on the neuroendocrine and immune system, with reduction in anxiety levels, depression, anger, fear, and stress, and improvement in NK and lymphocyte counts [86].

\section{Mindfulness-based interventions}

Mindfulness-based approaches in oncology acknowledge suffering as a normal part of cancer and cultivate acceptance of 
experiences to promote greater flexibility in coping with stress. Mindfulness emphasizes intentional focus on moment-to-moment experiences in a non-judgmental way [87]. Mindfulness interventions commonly focus on developing greater self-awareness, lowering reactivity in stressful situations, and mindful communication skills [87]. In cancer, mindfulness-based interventions have been shown to help patients cope with their feelings of loss of control, future uncertainty, and fears of recurrence that are associated with cancer diagnosis, treatment, and survivorship, while also providing psychological and overall-health-related benefits [88-90]. For example, one study of an 8-week mindfulness-based stress reduction (MBSR) program, including forty-nine breast cancer patients and ten prostate cancer patients, reported enhancement in quality of life, with decreased stress symptoms. At the same time, decrease in daily cortisol levels and Th1 (proinflammatory) cytokine levels, such as IFN- $\lambda$, TNF, IL-4, and IL-10, have been observed [91]. A number of recent meta-analyses have found that mindfulness-based interventions improved cancer patients' stress, anxiety, and depression [92-94]. Randomized trials also show the efficacy of mindfulness-based interventions to improve cancer patients' fatigue, insomnia, quality of life, psychological, behavioral, physiological, and biological markers of health [93, 95-98]. Many studies have investigated the use of holistic yoga (where yoga sessions varied, ranging from one to three times a week, each session lasting from 60 to $90 \mathrm{~min}$ ) in breast cancer patients, and showed statistically significant benefits with improvement in depression, stress, anxiety, physical well-being, quality of life, fatigue, cancer pain, cognitive function, and appetite, and an increased tolerance to chemotherapy side effects, though no essential survival benefit has been reported [99-111]. However, important questions remain related to the relative efficacy of mindfulness-based approaches compared to other stress reduction strategies, the appropriate dose and timing of mindfulness-based interventions, participant characteristics that shape intervention acceptability and efficacy, and the mechanisms through which mindfulness-based interventions impact stress.

\section{Acupuncture}

Multiple cancer- and treatment-related symptoms, such as depression, anxiety, hot flashes, neuropathy, nausea, vomiting, and radiation-induced xerostomia, result in stressful situations for breast cancer patients. Many breast cancer patients experience treatment-induced hot flashes and menopausal symptoms and instead of relying on medications, some seek other non-medical options. Acupuncture is one of the techniques that have shown advantages in distressed healthy adults [112]. A literature review reported that acupuncture enhances immune function through NK cell activity [113], based on stimulation of the acupoints, also known as "immuno- enhancing acupoint," thus enhancing nitric oxide production which promotes secretion of $\beta$-endorphin $[113,114]$. This peptide further reaches different locations of the body, and binds to opioid receptors expressed on surface of NK cells, which stimulates NK cells to release interferon-gamma (IFN$\gamma$ ), further inducing expression of NK cell receptors and secretion of cytokines from other immune cells, promoting anticarcinogenic immune functions [113-116]. Additionally, acupuncture may help breast cancer patients with menopausal symptoms via altering the autonomic nervous system [117]. Freedman et al. reported that hot flashes mainly occur because of sympathetic nervous system upregulation [118]. Acupuncture results in upregulation of parasympathetic nervous system, thus relieving symptoms of menopause [117]. Similarly, acupuncture has benefited cancer patients with vasomotor symptoms, anxiety, cancer-related pain, nausea, and vomiting [119-121]. By helping breast cancer patients deal with the above symptoms, acupuncture plays a role in improving stress levels in these patients. Though there is a benefit of utilizing acupuncture to help with quality of life measures in cancer patients, no survival benefit has been reported to date.

\section{Natural products}

The use of herbal and natural products has increased over the past decade. These products are used by patients to manage treatment-related symptoms, and also to help with psychological stress post diagnosis [122, 123]. A study reported that the most frequently used CAM were vitamins (70\%) and herbal products $(26 \%)$ [124]. These numbers could be underestimated as well, as studies reveal that approximately 46 to $60 \%$ of all cancer patients do not tell their healthcare provider about the use of CAM therapy $[125,126]$. Though patients take natural products and herbs to enhance their quality of life and for symptomatic management, there is little documented benefit of these products $[122,123]$. Since cancer is an inflammatory state resulting in oxidative stress with increased production of pro-inflammatory cytokines, reactive oxygen species, cyclooxygenase (COX-2), nuclear factor $\mathrm{kB}$ (NFKB), some of the herbal products like curcumin, Ashwagandha (Withania somnifera) exert immunomodulatory activity by interacting with these key mediators and exert antitumor effects $[127,128]$. A randomized clinical trial in subjects with history of chronic perceived stress using high concentration full-spectrum Ashwagandha root extract showed decrease in serum cortisol and improved resistance towards perceived stress and improved self-assessed quality of life [129]. Another prospective study in breast cancer patients showed that Ashwagandha resulted in improvement in cancer-related fatigue and quality of life, both of which indirectly result in better management of stress symptoms associated with breast cancer diagnosis and treatment [130]. Other commonly used natural and herbal products are, blue skullcap, 
gotu kola, guarana, kava, keenmind, lemon grass, passion flower and valerian. Kava when compared to others in the randomized controlled studies, showed benefit as an anxiolytic, while others showed no benefit [122]. However, use of kava has been associated with liver failure $[122,123,131]$ and additional research is warranted.

A number of studies have shown benefits with vitamin and mineral supplementation, including improvement in stress, anxiety, and fatigue. There is evidence that these supplements could enhance antidepressant effects [132, 133], and vitamin B levels, namely folic acid (B9), pyridoxine (B6), and cobalamins (B12), have been shown to be lower in patients under psychological stress [133-136]. One might then posit that supplementation may help deal with the stress symptoms.

However, the use of dietary supplements may also have negative effects on treatment outcomes. In this era where the use of herbal and natural products is on a rise, and without results from rigorous trials at hand, it is important to inquire about the use of these products from every patient. There has been concern that use of antioxidants, herbs and vitamins can interact with chemotherapy, radiotherapy, and hormonal treatment. Such use of CAM in combination with other therapies has been reported to cause severe side effects, and at other times negatively impacting the treatment outcomes [137, 138]. Recently, we reported results from an ancillary study conducted in the context of a SWOG clinical trial for highrisk breast cancer [139]. In that study, patients reported on use of supplements before and during chemotherapy. Results showed that use of any antioxidant (vitamins C, E, and A, carotenoids, coenzyme Q10) during treatment was associated with a $40 \%$ increase in hazard of recurrence as well as death. Use of iron supplements before and during chemotherapy, as well as use of vitamin B12, was associated with a twofold increase in hazard of death. Although use of supplements was self-reported, this study of more than 1300 breast cancer patients suggests that use of dietary supplements, particularly during chemotherapy, should be carefully considered by patients and their clinicians.

Given the current data, while consumption of some of the natural products may help manage stressful symptoms associated with breast cancer diagnosis and enhance quality of life; their use may not always be safe given increased toxicities and decreased survival reported recently [137, 138]. Hence, use of this approach to help alleviate symptoms should be considered with caution.

\section{Support groups and psychology counseling}

Dealing with a diagnosis of cancer can be difficult for patients. Connection with others experiencing cancer, such as through in-person or online support groups, may provide social and emotional support for some patients. Spiegel et al. reported that support group therapy in women with metastatic breast cancer resulted in a mean of 18 months longer survival in comparison to women in the control group [140-142]. This survival benefit through these support groups was later challenged by two randomized trials in breast cancer patients [143, 144]. Though these trials did not show that group therapy resulted in prolonged survival, they showed transient positive effects on mood and self-esteem, which indirectly resulted in improved stress levels $[143,144]$. Results of other similar studies in different cancer settings have been inconsistent and no firm conclusions could be reached from a survival standpoint $[145,146]$.

Increasing emotional support, mood stability, and reducing isolation are key factors to enhance quality of life and wellbeing. Therefore, when a patient is diagnosed with breast cancer and struggling with coping with multiple stressors associated with the diagnosis, it is important to have appropriate counseling. Multiple studies have demonstrated that psychology counseling sessions, which can be either in-person or through tele-medicine, have shown improvement in healthrelated quality of life in all subscales. Kim et al. reported that psychological intervention showed significant improvement in fatigue, depression, diet, and readiness to exercise in breast cancer patients [147]. Other trials offering psychological counseling demonstrated reductions in depression and improvement in social and spiritual well-being, ultimately helping to deal with and manage stress [148-150].

\section{Exercise}

In cancer patients, malignancy is a major source of fatigue, and treatment often adds significantly to stress. Patients are often counseled on the best ways to combat fatigue and stress, and exercise is a commonly recommended strategy to reduce these symptoms. For example, a study by Midtgaard et al. showed that patients receiving chemotherapy had improvement in psychological stress with an exercise regimen [151]. A study focusing on breast cancer patients receiving adjuvant chemotherapy showed that patients in the exercise group were found to have lower symptom severity scores and mood disturbance when compared to the non-exercise group patient population [152]. When focusing on early stage breast cancer, a study reported that patients who participated in a walking exercise program during radiation treatment had improvement in their fatigue, anxiety and sleep quality [153].

As discussed above, there is autonomic nervous system imbalance that can occur in cancer patients. The parasympathetic nervous system is responsible for vagal tone, which further accounts for heart rate variability (HRV) [154]. However, healthy adults, with lower HRV report more fatigue due to parasympathetic underactivity [155]. Similar results of low HRV have been observed in breast cancer survivors, which results in increased fatigue [156-158]. Exercise training and cardiopulmonary fitness result in increased HRV 
[159-161]. This is also evident in cancer patients, where a 16week exercise intervention during and after treatment resulted in an improvement in HRV, demonstrating that exercise is a modality that helps restore the existing autonomic nervous system imbalance in cancer patients [162].

Preclinical studies in 4T1 mammary carcinoma, a mouse model of triple-negative breast cancer (TNBC), have shown that exercise slowed tumor progression and reduced the tumor-induced accumulation of myeloid-derived suppressor cells (MDSCs) with a relative increase in natural killer (NK) and $\mathrm{CD}^{+} \mathrm{T}$ cell activation, resulting in a favorable immune environment [163]. Similar findings of exercise intervention in breast cancer patients with increased number and effector function of monocytes, macrophages, and NK cells have been observed [164]. Given the immuneenhancing ability of exercise interventions, the benefits have not just been limited to quality of life enhancement, but patients who exercise have also shown to have better survival outcomes. A recent study of newly diagnosed women with breast cancer in Australia randomized patients to either 8 -month exercise intervention or usual care after 6 weeks postsurgery. After a median follow-up of 8.3 years, there were $11(5.3 \%)$ deaths reported in the exercise group in comparison to $15(11.5 \%)$ deaths in usual care group, with hazard ratio (HR) of 0.45 (95\% CI $0.20-0.97)$ [165]. In a meta-analysis including 6 cohort studies with breast cancer patients, a HR of 0.66 (95\% CI 0.57-0.77) for breast cancer specific mortality and 0.59 (95\% CI $0.53-0.65)$ for overall survival (OS) was observed among patients involved in physical activity compared to patients with sedentary lifestyle [166]. Other studies have confirmed these findings [167]. Analysis of data from 5807 patients enrolled in the Roswell Park Comprehensive Cancer Center Shared Resource, the Data Bank and BioRepository, showed that habitual physical activity was associated with enhanced survival among patients with a number of cancers, including bladder, breast, colorectal, esophageal, prostate, skin, endometrial (uterine), and ovarian cancers [168]. Importantly, there was reduced risk among patients who had been physically inactive prior to diagnosis but began exercising after learning of their cancer. This beneficial effect of exercise on breast cancer could be due to decreased lifetime estrogen exposure, augmented immune function, lower body fat resulting in decrease in insulin resistance [166], or through other mechanisms. In the same ancillary study in the SWOG trial that assessed outcomes in relation to use of dietary supplement, we recently also queried patients about their recreational physical activity before, during, and after chemotherapy. In that study, patients who were meeting the Physical Activity Guidelines before and 1 year after diagnosis had significantly reduced hazard of recurrence $(\mathrm{HR}=$ $0.59,95 \%$ CI $0.42-0.82)$ and mortality ( $\mathrm{HR}=0.51,95 \% \mathrm{CI}$ 0.34-0.77) compared to inactive patients [169].
Thus, exercise before, during, and after treatment in breast cancer patients does not only enhance quality of life, reducing stress and anxiety, but also improves overall survival, and therefore, should be employed in clinical practice.

\section{Pharmacological management to suppress stress-induced $\beta$-AR signaling pathway}

Non-pharmacological strategies enhance quality of life by improving several symptoms, such as anxiety, stress, hot flashes, and fatigue in breast cancer patients as discussed above. However, there is limited data about a survival benefit with this approach. At the same time, it is challenging for patients battling cancer, who are dealing with physical and psychological stressors associated with the diagnosis, to further motivate themselves to indulge in these non-pharmacological strategies. As a result, in addition to non-pharmacological approaches, the use of pharmacological means has been explored in breast cancer patients to manage stress and the vicious cycle of adverse events triggered by stress.

Multiple prior studies have investigated the role of the $\beta$ adrenergic receptor signaling pathway in promoting breast cancer progression and role of pharmacologic approaches to inhibit this pathway. Another stress signaling pathway is the HPA axis as discussed before which promotes breast cancer cell growth, especially TNBC by acting on GR on the tumor cell. The role of GR signaling in breast cancer is evolving as data shows that dexamethasone administration in preclinical TNBC models can lead to cancer progression. This study showed that increase in stress hormones during breast cancer progression (cortisol, corticosterone, and ACTH) results in activation of the GR at distant metastatic sites, increased colonization, and reduced survival [170]. This knowledge is of utmost importance, particularly in the clinics, where glucocorticoids are used as anti-emetic and anti-inflammatory agents. With the recent approval of checkpoint inhibitors in TNBC, the use of glucocorticoids will further increase in breast cancer for the management of immune-related adverse events from checkpoint inhibitors [171]. Hence, data shows that glucocorticoids should be cautiously used in TNBC. In addition, these findings also highlight the importance of better stress management to abrogate this signaling pathway in breast cancer patients where higher cortisol levels have been observed [53]. Over the last few years, studies have shown that GR signaling in TNBC results in worse relapse-free survival, but its correlation with stress perception has not been investigated [172]. This interesting interaction of the stress pathway involving HPA axis, GR and its signaling is evolving and further study of this area is warranted to develop approaches to target this pathway to improve outcomes [173]. Preclinical studies have shown that GR antagonists can overcome chemotherapy resistance in TNBC [174]. Since GR is highly expressed in 
TNBC, clinical trials are actively investigating if GR antagonists such as mifepristone and CORT125134 in combination with chemotherapy could help improve survival of GRpositive TNBC [175]. A detailed discussion of the GR signaling pathway is beyond the scope of this review.

This article focuses on discussion of the stress-induced $\beta$ AR signaling pathway in breast cancer patients and highlights both preclinical and clinical studies targeting this pathway to inhibit cancer growth and improve survival outcomes.

\section{Preclinical studies using pharmacologic blockade}

Stress results in activation of the SNS which releases neurotransmitters epinephrine and NE that act on $\beta$-adrenergic receptors. As discussed, the $\beta$-adrenergic signaling pathway plays a key role in tumor progression via direct protumorigenic effect on cancer cells and inhibition of anticancer immunity. To combat these mechanisms, several preclinical studies have explored the role of repurposing $\beta$ blockers as an effective anti-tumor armamentarium since it is relatively inexpensive and safe. Both selective (metoprolol, atenolol) and non-selective $\beta$-blockers (propranolol) have been studied in various preclinical cancer models. Interestingly, non-selective $\beta 1 / 2$-receptor antagonists like propranolol have shown to decrease tumor growth and migration of cancer cells $[68,70,72,176]$. However, studies with $\beta 1$-selective antagonists like atenolol did not demonstrate similar tumor inhibitory effects [68, 70, 177]. These studies highlight the crucial role played by $\beta 2$-adrenergic signaling in tumorigenesis. $\beta 2$-Adrenergic receptors are present both on the tumor cells and immune cells and abrogation of the signaling pathway via non-selective $\beta$-blockers is able to reverse the pro-tumorigenic cascade [39].

An "acute stress" is considered to be a single event that lasts minutes to hours, such as exposure to predator, which may activate the sympathetic "fight or flight" response and is then resolved, thus allowing the animal to return to its resting state [178]. On the other hand, "chronic stress" lasts for an extended period of time with no resolution and is known to have suppressive effects on immunity. This detrimental effect on immune cell function is mainly because of long and sustained physiological response, resulting in increase in catecholamine and glucocorticoid hormones [178, 179]. In preclinical models, there are several ways to mimic chronic stress such as social isolation, fear-inducing stimuli or cold stress of housing temperature, over long period of time [180]. Chronic stress results in higher levels of tissue catecholamines and greater tumor growth as seen in an orthotopic ovarian cancer mouse model. Increased NE primarily activates the tumor cell cyclic AMP (cAMP)-protein kinase A (PKA) signaling pathway by $\beta 2$-receptor activation on ovarian cancer cells to trigger an increase in the expression of the vascular endothelial growth factor (VEGF) gene, resulting in enhanced tumor vascularization and aggressive growth and spread of malignant cells. Propranolol was shown to inhibit the $\beta$-receptordependent activation [181]. Choy et al. showed that the breast cancer cell line MDA-MB231, both primary and brain metastases cells, expressed the $\beta 2$-adrenergic receptor. Treatment with propranolol resulted in development of brain metastases at a significantly decreased rate $(p<0.001)$ compared to the control cells [182].

Stress in an orthotopic mouse model of breast cancer resulted in increased infiltration with macrophages in the primary tumor parenchyma, with M2 differentiation, and thus induced a prometastatic gene expression. Propranolol treatment reversed the stress-induced macrophage infiltration and inhibited tumor spread. Macrophage suppression via CSF-1 receptor kinase inhibitor also inhibited formation of distant metastases, thus showing that $\beta$-adrenergic signaling has been shown to induce a pro-metastatic environment in primary breast cancer [72]. Another study has shown that chronic stress leads to increased $\beta$-adrenergic signaling resulting in creation of a "prometastatic" niche in the lungs, favoring colonization with circulating breast cancer cells. Increased $\beta$-adrenergic signaling upregulates the expression of CCL2 in the pulmonary stromal cells and CCR2 in monocytes/macrophages, thus recruiting macrophages into the pre-metastatic lung. Propranolol suppressed this stress-induced lung metastasis [183]. Nagaraja et al. showed that increased $\beta$-adrenergic signaling promoted pro-tumor and pro-metastatic cancer-associated fibroblasts (CAF) via induction of inhibin $\beta$ A (INHBA) production by cancer cells after NE stimulation, resulting in increased collagen deposition in tumors. This resulted in potentiation of migration and invasion of cancer cells and decreased access of chemotherapy/immunotherapy along with cytotoxic T-cells. These effects were abrogated by propranolol by decrease in $\alpha$-smooth muscle actin (SMA) levels and thus reduced expression of CAF markers and INHBA [184].

$\beta 2$-Adrenergic receptor (AR) is the primary subtype expressed on immune cells (including T-cells, B-cells, dendritic cells, and macrophages) [185, 186]. Our group showed that chronic stress via NE production acts on the $\beta 2$ adrenergic receptors present on the $\mathrm{CD}^{+} \mathrm{T}$-cells in a $4 \mathrm{~T} 1$ murine breast cancer model, thus limiting anti-tumor immunity. This effect can be blocked by treatment with propranolol or via using $\beta 2$-receptor knockout mice, thus resulting in the restoration of anti-tumor immunity as evidenced by increased expression of markers of effector function (T-bet, IFN $\gamma$, and GzmB) and a significantly increased ratio of $\mathrm{IFN}^{+} \mathrm{CD}^{+}$: Treg cells indicative of an inflammatory tumor microenvironment (TME). Since 4T1 cells do not express any $\beta$-receptors, the decrease in tumor growth seen with propranolol is attributed to the improved anti-tumor immune response induced with propranolol treatment. In addition, $\mathrm{CD}^{+} \mathrm{T}$ cells in propranolol-treated mice also expressed lower levels of PD1 , which also improves the responses of these tumors to anti- 
programmed death receptor-1 (PD-1) checkpoint blockade therapy [47]. We also found that one mechanism by which $\beta 2-\mathrm{AR}$ signaling can inhibit $\mathrm{CD} 8^{+} \mathrm{T}$ cell activation is by metabolic reprogramming (glycolysis and mitochondrial oxidative phosphorylation) which is observed when the immune cells are activated. Murine $\mathrm{CD} 8^{+} \mathrm{T}$ cells treated with pan $\beta$ AR agonist, isoproterenol (ISO), have reduced expression of glucose transporter 1 and decreased glucose uptake and glycolysis, compared to cells activated in the absence of ISO. The effect of ISO was specifically dependent upon $\beta 2$-AR, since it was not observed in $\mathrm{ADRB} 2^{-} \digamma \mathrm{CD} 8^{+} \mathrm{T}$ cells and was also blocked by propranolol [41]. In addition to the impact of $\beta 2$-AR signaling pathway on $\mathrm{CD} 8^{+} \mathrm{T}$ cells, our group showed that chronic stress acting via $\beta 2$-receptor signaling results in promotion of proliferation and survival of myeloid derived suppressor cells (MDSC) in a murine breast cancer model [46], leading to suppression of antitumor immune response. The authors also show that inhibiting $\beta 2$-AR signaling pathway by non-selective blocker, propranolol; or using $\beta 2-\mathrm{AR}^{-} \digamma$ MDSC could decrease MDSC accumulation, their immunosuppressive function, and thus increase efficacy of antitumor immune response and inhibition of tumor growth.

Findings from these preclinical models of chronic stress are applicable to the clinical setting when patients are diagnosed with cancer, as the physical and psychological symptoms from cancer diagnosis along with cancer treatment is considered a long-standing stressful situation for these patients.

\section{Clinical studies using pharmacological blockade}

There have been several studies in literature so far reporting on the role of impeding the stress associated $\beta$-AR signaling pathway to improve cancer-related outcomes. Here, we cite some examples of retrospective studies and prospective clinical trials in breast cancer highlighting the importance of targeting this pathway. Barron et al. prospectively collected data from the National Cancer Registry Ireland (NCRI) to identify women diagnosed with stage I-IV breast cancer. Patients were stratified into those taking propranolol or atenolol or no $\beta$-blockers before breast cancer diagnosis for non-oncologic reasons. Breast cancer patients on propranolol were significantly less likely to present with advanced stage tumor (T4 or N2/N3/M1) and furthermore had a lower breast cancer-specific mortality (HR 0.19, 95\% CI 0.06-0.60) when compared to matched non-users. However, on the other hand, there was no difference between advanced stage tumor presentation or breast cancer mortality among patients on $\beta 1$-selective blocker atenolol compared to matched non-users. This clearly demonstrates and concurs with the preclinical findings that the effect of propranolol are the result of $\beta 2-\mathrm{AR}$ antagonism [187].

A retrospective study by Choy et al. showed that for stage II breast cancer patients, treatment with $\beta$-blocker perioperatively significantly reduced the risk of postoperative recurrence or distant metastasis (HR 0.51 ; 95\% CI $0.23-0.97, p=0.041$ ) [182]. In another retrospective cohort study, non-selective $\beta$ blocker (but not selective $\beta$-blocker) was shown to decrease the tumor proliferative index $(\mathrm{Ki} 67)$ by $66 \%(p<0.001)$ in earlystage breast cancer. In addition, on prospective analysis of one patient, propranolol treatment resulted in reduction in Ki67 by $23 \%$ between pretreatment and posttreatment biopsy [188]. These findings could be explained by the fact that psychological stress is increased following a diagnosis of breast cancer, especially, at the time of surgery. A prospective study randomized breast cancer patients to control and propranolol groups after undergoing modified radical mastectomy until day 3 postsurgery and peripheral blood samples were collected until 7 days postsurgery. The study showed that surgery results in an increase in the number of immunosuppressive T-regulatory cells (Treg), thus showing that chronic stress is immunosuppressive and could contribute to future recurrence; however, the Treg increase was abrogated with propranolol treatment [189]. A recent prospective clinical trial including all breast cancer subtypes showed that preoperative $\beta$-blocker downregulated biomarkers of invasive potential and improved biomarkers of cellular immune response within the breast tumor. Interestingly, the study showed that patients with clinical evidence of disease response (lowered heart rate and blood pressure) showed elevated tumor infiltration of $\mathrm{CD} 68^{+}$macrophages and $\mathrm{CD} 8^{+} \mathrm{T}$ cells [190]. These studies have analyzed and confirmed the importance of $\beta$-blockade on recurrence and proliferation markers in early stage breast cancer patients in the pre- and perioperative setting.

The impact of $\beta$-AR blockade on cancer outcomes appears to be independent of breast cancer subtype with clinical responses in TNBC and Her2-positive breast cancer, and its role in hormone-receptor positive breast cancer is still being investigated. In a retrospective study of 800 postmenopausal TNBC patients, $\beta$-blocker intake (for non-oncologic reasons) improved recurrence-free survival (RFS) in women with TNBC and also reduced the risk of metastases [191]. Another study shows that trastuzumab-resistance-dependent $\mathrm{PI} 3 \mathrm{~K} / \mathrm{AKT} / \mathrm{mTOR}$ pathway is controlled by catecholamineinduced $\beta 2$-AR pathway. Studies have shown that propranolol treatment not only enhances the activity of trastuzumab but also resensitizes the resistant cells to trastuzumab. Retrospective case-control study showed improved PFS and OS in the population on concurrent propranolol, trastuzumab, and chemotherapy treatment compared to only trastuzumab and chemotherapy in Her2-overexpressing metastatic breast cancer [192]. Table 1 shows examples of other studies which report the positive impact of beta-blocker use specifically in breast cancer patients on recurrence and mortality [35, 193-195].

Based on the above studies, besides the standard use of $\beta$ blockers in medical indications, like cardiac arrhythmias, hypertension, infantile hemangioma, thyrotoxicosis, tremors, 
Table 1 Overview of some retrospective studies and metaanalysis reporting outcomes with beta-blocker use in breast cancer

\begin{tabular}{|c|c|c|c|}
\hline Study & Population & $\begin{array}{l}\text { Timing of } \beta \text { - } \\
\text { blocker use }\end{array}$ & Breast cancer outcomes \\
\hline Childers et al. & $\begin{array}{l}\text { Meta-analysis of } 7 \text { studies: } \\
\text { systematic review using } \\
\text { Cochrane library and } \\
\text { PubMed }\end{array}$ & - & $\begin{array}{l}\text { No statistically significant } \\
\text { reduction in breast cancer } \\
\text { recurrence. Significant } \\
\text { reduction in breast cancer death } \\
\text { (HR 0.50; 95\% CI 0.32-0.80). } \\
\text { No significant effect of } \\
\beta \text {-blockers on all-cause } \\
\text { mortality (HR, } 1.02 ; 95 \% \text { CI, } \\
0.75-1.37 \text { ) [35] }\end{array}$ \\
\hline Ganz et al. & $\begin{array}{l}\text { LACE (Life After Cancer } \\
\text { Epidemiology) cohort: } \\
\text { Early stage invasive } \\
\text { breast cancer }\end{array}$ & $\begin{array}{l}\beta \text {-blocker use in the } \\
\text { year prior to or } \\
\text { after breast } \\
\text { cancer diagnosis }\end{array}$ & $\begin{array}{l}\beta \text {-blocker use was associated with } \\
\text { lower hazard of recurrence (HR } \\
0.86 \text { ) and cause-specific } \\
\text { mortality (HR 0.76) but not } \\
\text { statistically significant [193] }\end{array}$ \\
\hline $\begin{array}{l}\text { Melhem-Bretrandt } \\
\text { et al. }\end{array}$ & $\begin{array}{l}\text { Retrospective analysis in } \\
\text { breast cancer patients } \\
\text { receiving neoadjuvant } \\
\text { chemotherapy }\end{array}$ & $\begin{array}{l}\beta \text {-blocker use at the } \\
\text { start of } \\
\text { neoadjuvant } \\
\text { chemotherapy }\end{array}$ & $\begin{array}{l}\beta \text {-blocker intake was associated } \\
\text { with a significantly better RFS } \\
\text { (HR } 0.52,95 \% \text { CI } 0.31 \text { to } 0.88 \text { ) } \\
\text { but not OS. Among patients with } \\
\text { TNBC, } \beta \text {-blocker intake was } \\
\text { associated with improved RFS } \\
\text { (HR } 0.30 ; 95 \% \text { CI } 0.10 \text { to } 0.87 \text {; } \\
p=0.027 \text { ) but not OS. }[194]\end{array}$ \\
\hline Powe et al. & $\begin{array}{l}\text { Retrospective study in } \\
\text { patients with operable } \\
\text { breast cancer }\end{array}$ & $\begin{array}{l}\beta \text {-blocker use prior } \\
\text { to cancer } \\
\text { diagnosis }\end{array}$ & $\begin{array}{l}\beta \text {-blocker-treated patients showed } \\
\text { a significant reduction in } \\
\text { metastasis development } \\
(p=0.026) \text {, tumor recurrence } \\
(p=0.001) \text {, and longer } \\
\text { disease-free interval }(p=0.01) \text {. } \\
\text { In addition, there was a 57\% } \\
\text { reduced risk of metastasis } \\
\text { (hazards ratio }=0.430 ; 95 \% \\
\text { CI }=0.200-0.926, p=0.031), \\
\text { and a 71\% reduction in breast } \\
\text { cancer mortality after } 10 \text { years } \\
\text { (Hazards ratio }=0.291 ; 95 \% \\
\text { CI }=0.119-0.715, p=0.007) \\
{[195] .}\end{array}$ \\
\hline
\end{tabular}

migraine prophylaxis, cluster or tension headache, $\beta$-blockers have emerged as a significant repurposing agent in oncology due to its ability to abrogate the adrenergic signaling pathway via its anti-proliferative, anti-angiogenic, anti-lymphangiogenic, pro-apoptotic, and immunomodulating effects. There is some preclinical data for anti-cancer efficacy for carvedilol and atenolol [196-198]; however, most of the preclinical studies have used propranolol. In clinical practice, the frequently prescribed non-selective $\beta$-blockers are carvedilol, labetalol, nadolol, and sotalol for non-oncologic reasons as discussed above. New preclinical studies in the future should consider utilizing the more commonly prescribed $\beta$-blockers, in addition to propranolol so the findings could be translated into real-world practice. The $\beta$ adrenergic affinity for all these agents vary and new research and future studies will be needed to show if breast cancer subtypes with different expression levels will be sensitive to different $\beta$-blockers.

\section{Future directions}

Preclinical studies as discussed above show that stress can act not only on the tumor and stromal cells but also on the immune cells creating an immunosuppressive milieu which promotes tumor growth. Inhibition of $\beta 2-A R$ signaling is an effective mechanism to overcome the detrimental impact of chronic stress in cancer. There has been increasing interest in bench-to-bedside translation of this important finding which potentially may provide a promising avenue for managing stress among breast cancer patients.

Retrospective studies have several limitations which include presence of different comorbidities, type, dose, and duration of use of different $\beta$-blockers for which it is difficult to control the retrospective data. Hence, there is a need to investigate their use in prospective clinical trials in addition to standard chemotherapeutic and immunotherapeutic modalities to improve cancer 
outcomes. Several clinical trials in breast cancer are evaluating this crucial role of propranolol in early stage and metastatic breast cancer (NCT01847001, NCT02013492). Both studies being performed are expanding on the previous laboratory data which demonstrates that propranolol inhibits breast cancer progression. NCT01847001 is investigating the combination of propranolol with chemotherapy in influencing biomarkers, like Ki67, tumor density and change in stress score levels in the neoadjuvant setting in early-stage breast cancer. NCT02013492 is studying the role of propranolol on the tumor microenvironment and host immune system, in addition to survival outcomes in the metastatic setting.

\section{Conclusion}

Cancer affects patients and their families in many ways, increasing stressful conditions, physically, mentally, and emotionally. Multiple studies have shown that stress promotes breast cancer growth. To reduce cancer-related stress, patients can use several modalities, mainly pharmacological or non-pharmacological. The use of CAM techniques in assisting patients to enhance their quality of life has been on a rise. There is an important opportunity for transdisciplinary research to integrate findings from preclinical and clinical studies on anti-tumor immunity to understand the potential of common non-pharmacological stress reduction strategies (such as mindfulness and exercise) to alter the relationship between stress and cancer progression. Use of $\beta$-blockers to inhibit the elevated $\beta 2$-adrenergic receptor signaling observed in cancer patients experiencing stress has been shown to decrease tumor progression both in preclinical and clinical studies, and offers a relatively inexpensive and safe option to combine with standard of care cancer treatments. In the future, if there is a way to quantify stress with a stress signature, it may provide us with a biomarker to streamtailor the targeted use of non-pharmacologic and pharmacologic strategies to this population.

Author contributions R.G., E.R., and S.G. conceived the idea for the article; R.G., S.G., E.B., C.A., and E.R. performed the literature search and drafted the review; R.G. and S.G. critically revised the work.

Funding This project was supported by the National Institutes of Health (NIH) grants, R01 CA205246, and R01 CA099326 (to E.R.); the Roswell Park Alliance Foundation (to S.G.); Breast Cancer Research Foundation (to CA), NCI R01CA225947 (MPI), U01CA195565 (MPI) (to C.A.). Research reported in this publication was also supported by the National Center for Advancing Translational Sciences of the National Institute of Health under award number 5KL2TR0013-05 and UL1TR0012-05 (to S.G.). The content is solely the responsibility of the authors and does not necessarily represent the official views of the NIH.

\section{Compliance with ethical standards}

Conflict of interest The authors declare that they have no conflicts of interest.
Ethical approval This article does not contain any studies with human participants or animals performed by any of the authors.

Open Access This article is licensed under a Creative Commons Attribution 4.0 International License, which permits use, sharing, adaptation, distribution and reproduction in any medium or format, as long as you give appropriate credit to the original author(s) and the source, provide a link to the Creative Commons licence, and indicate if changes were made. The images or other third party material in this article are included in the article's Creative Commons licence, unless indicated otherwise in a credit line to the material. If material is not included in the article's Creative Commons licence and your intended use is not permitted by statutory regulation or exceeds the permitted use, you will need to obtain permission directly from the copyright holder. To view a copy of this licence, visit http://creativecommons.org/licenses/by/4.0/.

\section{References}

1. American Cancer Society (2017) What are the key statistics about breast cancer? https://www.cancer.org/cancer/breast-cancer/ about/how-common-is-breast-cancer.html. Accessed 5 Jul 2019

2. U.S. Breast Cancer Statistics, 2019 (2019) https://www. breastcancer.org/symptoms/understand_bc/statistics. Accessed 5 Jul 2019

3. Teegarden D, Romieu I, Lelièvre SA (2012) Redefining the impact of nutrition on breast cancer incidence: is epigenetics involved? Nutr Res Rev. https://doi.org/10.1017/ s0954422411000199

4. Youlden DR, Cramb SM, Yip CH, Baade PD (2014) Incidence and mortality of female breast cancer in the AsiaPacific region. $\mathrm{J}$ Cancer Bio Meical. https://doi.org/10.7497/j.issn.2095-3941. 2014.02.005

5. Torre LA, Bray F, Siegel RL et al (2015) Global cancer statistics, 2012. CA Cancer J Clin 65:87-108. https://doi.org/10.3322/caac. 21262

6. Bray F, Ferlay J, Soerjomataram I et al (2018) Global cancer statistics 2018: GLOBOCAN estimates of incidence and mortality worldwide for 36 cancers in 185 countries. CA Cancer J Clin. https://doi.org/10.3322/caac.21492

7. Rudolph A, Chang-Claude J, Schmidt MK (2016) Geneenvironment interaction and risk of breast cancer. $\mathrm{Br} \mathrm{J}$ Cancer 114:125-133. https://doi.org/10.1038/bjc.2015.439

8. Hwang JH, Kim W-Y, Ahmed M et al (2015) The use of complementary and alternative medicine by Korean breast cancer women: is it associated with severity of symptoms? Evidence-Based Complement Altern Med. https://doi.org/10.1155/2015/182475

9. Pinquart M, Duberstein PR (2010) Depression and cancer mortality: a meta-analysis. Psychol Med. https://doi.org/10.1017/ S0033291709992285

10. Nowicki A, Krzemkowska E, Rhone P (2015) Acceptance of illness after surgery in patients with breast cancer in the early postoperative period. Pol Prz Chir Polish J Surg. https://doi.org/10. 1515/pjs-2016-0001

11. Dillard AJ, Scherer L, Ubel PA et al (2013) Breast cancer anxiety's associations with responses to a chemoprevention decision aid. Soc Sci Med. https://doi.org/10.1016/j.socscimed.2012. 10.009

12. Vodermaier A, Linden W, Rnic K et al (2014) Prospective associations of depression with survival: a population-based cohort study in patients with newly diagnosed breast cancer. Breast Cancer Res Treat. https://doi.org/10.1007/s10549-013-2795-4

13. Bower JE (2014) Cancer-related fatigue-mechanisms, risk factors, and treatments. Nat Rev Clin Oncol 
14. Hall DL, Antoni MH, Lattie EG et al (2015) Perceived fatigue interference and depressed mood: comparison of chronic fatigue syndrome/myalgic encephalomyelitis patients with fatigued breast cancer survivors. Fatigue Biomed Heal Behav. https://doi.org/10. 1080/21641846.2015.1039289

15. Charlson ME, Loizzo J, Moadel A et al (2014) Contemplative self healing in women breast cancer survivors: a pilot study in underserved minority women shows improvement in quality of life and reduced stress. BMC Complement Altern Med. https://doi.org/10. 1186/1472-6882-14-349

16. Meneses-Echávez JF, González-Jiménez E, Ramírez-Vélez R (2015) Effects of supervised exercise on cancer-related fatigue in breast cancer survivors: a systematic review and meta-analysis. BMC Cancer. https://doi.org/10.1186/s12885-015-1069-4

17. Langford DJ, Paul SM, Cooper B et al (2016) Comparison of subgroups of breast cancer patients on pain and co-occurring symptoms following chemotherapy. Support Care Cancer. https://doi.org/10.1007/s00520-015-2819-1

18. Dodd MJ, Cho MH, Cooper BA, Miaskowski C (2010) The effect of symptom clusters on functional status and quality of life in women with breast cancer. Eur J Oncol Nurs. https://doi.org/10. 1016/j.ejon.2009.09.005

19. Kent EE, Rowland JH, Northouse L et al (2016) Caring for caregivers and patients: research and clinical priorities for informal cancer caregiving. Cancer

20. Van Ryn M, Sanders S, Kahn K et al (2011) Objective burden, resources, and other stressors among informal cancer caregivers: a hidden quality issue? Psychooncology. https://doi.org/10.1002/ pon. 1703

21. Hasson-Ohayon I, Goldzweig G, Braun M, Galinsky D (2010) Women with advanced breast cancer and their spouses: diversity of support and psychological distress. Psychooncology. https:// doi.org/10.1002/pon.1678

22. Shaffer KM, Kim Y, Carver CS, Cannady RS (2017) Depressive symptoms predict cancer caregivers' physical health decline. Cancer. https://doi.org/10.1002/cncr.30835

23. Kim Y, Carver CS, Shaffer KM et al (2015) Cancer caregiving predicts physical impairments: roles of earlier caregiving stress and being a spousal caregiver. Cancer. https://doi.org/10.1002/ cncr.29040

24. Litzelman K, Kent EE, Rowland JH (2018) Interrelationships between health behaviors and coping strategies among informal caregivers of Cancer survivors. Health Educ Behav. https://doi. org/10.1177/1090198117705164

25. Di Gregorio SW, Carpenter KM, Dorfman CS et al (2012) Impact of breast cancer recurrence and cancer-specific stress on spouse health and immune function. Brain Behav Immun. https://doi.org/ 10.1016/j.bbi.2011.07.237

26. Applebaum AJ, Breitbart W (2013) Care for the cancer caregiver: a systematic review. Palliat Support Care

27. Stenberg U, Ruland CM, Miaskowski C (2010) Review of the literature on the effects of caring for a patient with cancer. Psychooncology

28. Dionne-Odom JN, Demark-Wahnefried W, Taylor RA et al (2017) The self-care practices of family caregivers of persons with poor prognosis cancer: differences by varying levels of caregiver well-being and preparedness. Support Care Cancer. https://doi. org/10.1007/s00520-017-3650-7

29. Litzelman K, Kent EE, Mollica M, Rowland JH (2016) How does caregiver well-being relate to perceived quality of care in patients with cancer? Exploring associations and pathways. J Clin Oncol. https://doi.org/10.1200/JCO.2016.67.3434

30. Segrin C, Badger TA, Sikorskii A et al (2018) A dyadic analysis of stress processes in Latinas with breast cancer and their family caregivers. Psychooncology. https://doi.org/10.1002/pon.4580
31. Greenlee H, Balneaves LG, Carlson LE et al (2014) Clinical practice guidelines on the use of integrative therapies as supportive care in patients treated for breast cancer. J Natl Cancer Inst Monogr. https://doi.org/10.1093/jncimonographs/lgu041

32. Kenne Sarenmalm E, Mårtensson LB, Holmberg SB et al (2013) Mindfulness based stress reduction study design of a longitudinal randomized controlled complementary intervention in women with breast cancer. BMC Complement Altern Med. https://doi. org/10.1186/1472-6882-13-248

33. Lamothe M, Rondeau É, Malboeuf-Hurtubise C et al (2016) Outcomes of MBSR or MBSR-based interventions in health care providers: a systematic review with a focus on empathy and emotional competencies. Complement Ther Med

34. Nakamura Y, Lipschitz DL, Kuhn R et al (2013) Investigating efficacy of two brief mind-body intervention programs for managing sleep disturbance in cancer survivors: a pilot randomized controlled trial. J Cancer Surviv. https://doi.org/10.1007/s11764012-0252-8

35. Childers WK, Hollenbeak CS, Cheriyath P (2015) $\beta$-Blockers reduce breast cancer recurrence and breast cancer death: a metaanalysis. Clin Breast Cancer 15:426-431. https://doi.org/10.1016/ j.clbc.2015.07.001

36. Fitzgerald PJ (2009) Is norepinephrine an etiological factor in some types of cancer? Int J Cancer

37. Armaiz-Pena GN, Lutgendorf SK, Cole SW, Sood AK (2009) Neuroendocrine modulation of cancer progression. Brain Behav Immun

38. Thaker PH, Lutgendorf SK, Sood AK (2007) The neuroendocrine impact of chronic stress on cancer. Cell Cycle

39. Cole SW, Sood AK (2012) Molecular pathways: beta-adrenergic signaling in cancer. Clin Cancer Res. https://doi.org/10.1158/ 1078-0432.CCR-11-0641

40. Chakroborty D, Sarkar C, Basu B et al (2009) Catecholamines regulate tumor angiogenesis. Cancer Res

41. Qiao G, Bucsek MJ, Winder NM et al (2019) $\beta$-Adrenergic signaling blocks murine CD8 + T-cell metabolic reprogramming during activation: a mechanism for immunosuppression by adrenergic stress. Cancer Immunol Immunother. https://doi.org/10. 1007/s00262-018-2243-8

42. Yang EV, Sood AK, Chen M et al (2006) Norepinephrine upregulates the expression of vascular endothelial growth factor, matrix metalloproteinase (MMP)-2, and MMP-9 in nasopharyngeal carcinoma tumor cells. Cancer Res. https://doi.org/10.1158/ 0008-5472.CAN-06-2496

43. Palm D, Lang K, Niggemann B et al (2006) The norepinephrinedriven metastasis development of PC-3 human prostate cancer cells in BALB/c nude mice is inhibited by $\beta$-blockers. Int $\mathbf{J}$ Cancer. https://doi.org/10.1002/ijc.21723

44. Al-Wadei HA, Al-Wadei MH, Schuller HM (2009) Prevention of pancreatic cancer by the beta-blocker propranolol. Anti-Cancer Drugs. https://doi.org/10.1097/CAD.0b013e32832bd1e3

45. Eng JWL, Reed CB, Kokolus KM et al (2015) Housing temperature-induced stress drives therapeutic resistance in murine tumour models through $\beta 2$-adrenergic receptor activation. Nat Commun. https://doi.org/10.1038/ncomms 7426

46. Mohammadpour H, MacDonald CR, Qiao G et al (2019) $\beta 2$ adrenergic receptor-mediated signaling regulates the immunosuppressive potential of myeloid-derived suppressor cells. J Clin Invest. https://doi.org/10.1172/jci129502

47. Bucsek MJ, Qiao G, MacDonald CR et al (2017) $\beta$-Adrenergic signaling in mice housed at standard temperatures suppresses an effector phenotype in CD8+ T cells and undermines checkpoint inhibitor therapy. Cancer Res 77:5639-5651. https://doi.org/10. 1158/0008-5472.CAN-17-0546

48. Eng JWL, Kokolus KM, Reed CB et al (2014) A nervous tumor microenvironment: the impact of adrenergic stress on cancer cells, 
immunosuppression, and immunotherapeutic response. Cancer Immunol Immunother

49. Baum A, Cohen L, Hall M (1993) Control and intrusive memories as possible determinants of chronic stress. Psychosom Med

50. Zhang C, Wenger T, Mattern J et al (2007) Clinical and mechanistic aspects of glucocorticoid-induced chemotherapy resistance in the majority of solid tumors. Cancer Biol Ther. https://doi.org/ 10.4161/cbt.6.2.3652

51. Smith SM, Vale WW (2006) The role of the hypothalamicpituitary-adrenal axis in neuroendocrine responses to stress. Dialogues Clin Neurosci 8:383-395

52. Sephton S, Spiegel D (2003) Circadian disruption in cancer: a neuroendocrine-immune pathway from stress to disease? Brain Behav Immun 17:321-328. https://doi.org/10.1016/s08891591(03)00078-3

53. Van Der Pompe G, Antoni MH, Heijnen CJ (1996) Elevated basal cortisol levels and attenuated ACTH and cortisol responses to a behavioral challenge in women with metastatic breast cancer. Psychoneuroendocrinology. https://doi.org/10.1016/03064530(96)00009-1

54. Kach J, Conzen SD, Szmulewitz RZ (2015) Targeting the glucocorticoid receptor in breast and prostate cancers. Sci Transl Med 7: 305ps19. https://doi.org/10.1126/scitranslmed.aac7531

55. Van Der Pompe G, Antoni MH, Mulder CL et al (1994) Psychoneuroimmunology and the course of breast cancer: an overview the impact of psychosocial factors on progression of breast cancer through immune and endocrine mechanisms. Psycho-Oncology. https://doi.org/10.1002/pon.2960030404

56. Goldstein DS (2010) Adrenal responses to stress. In: Cellular and Molecular Neurobiology

57. Zhang D, Ma Q, Wang Z et al (2011) $\beta$ 2-adrenoceptor blockage induces $\mathrm{G} 1 / \mathrm{S}$ phase arrest and apoptosis in pancreatic cancer cells via Ras/Akt/NFkB pathway. Mol Cancer. https://doi.org/10.1186/ 1476-4598-10-146

58. Nagmani R, Pasco DS, Salas RD, Feller DR (2003) Evaluation of $\beta$-adrenergic receptor subtypes in the human prostate cancer cell line-LNCaP. Biochem Pharmacol. https://doi.org/10.1016/S00062952(03)00105-9

59. Moretti S, Massi D, Farini V et al (2013) $\beta$-Adrenoceptors are upregulated in human melanoma and their activation releases pro-tumorigenic cytokines and metalloproteases in melanoma cell lines. Lab Investig. https://doi.org/10.1038/labinvest.2012.175

60. Draoui A, Vandewalle B, Hornez L et al (1991) $\beta$-Adrenergic receptors in human breast cancer: identification, characterization and correlation with progesterone and estradiol receptors. Anticancer Res

61. Kondratenko T, Zakharova I, Kuzina N (2004) Human lung cancer: alterations of parenchymal $\alpha 1$-adrenergic receptors. Eur J Cancer. https://doi.org/10.1016/0959-8049(93)91507-h

62. Reisine T, Heisler S, Hook V, Axelrod J (2018) Activation of beta 2 -adrenergic receptors on mouse anterior pituitary tumor cells increases cyclic adenosine $3^{\prime}: 5^{\prime}$-monophosphate synthesis and adrenocorticotropin release. J Neurosci. https://doi.org/10.1523/ jneurosci.03-04-00725.1983

63. Valles SL, Benlloch M, Rodriguez ML et al (2013) Stress hormones promote growth of B16-F10 melanoma metastases: an interleukin 6- and glutathione-dependent mechanism. J Transl Med. https://doi.org/10.1186/1479-5876-11-72

64. Lutgendorf SK, Sood AK, Antoni MH (2010) Host factors and cancer progression: biobehavioral signaling pathways and interventions. J Clin Oncol

65. Antoni MH, Lutgendorf SK, Cole SW et al (2006) The influence of bio-behavioural factors on tumour biology: pathways and mechanisms. Nat Rev Cancer
66. Entschladen F, Drell VITL, Lang K et al (2004) Tumour-cell migration, invasion, and metastasis: navigation by neurotransmitters. Lancet Oncol

67. Fidler IJ (2003) The pathogenesis of cancer metastasis: the "seed and soil" hypothesis revisited. Nat Rev Cancer

68. Masur K, Niggemann B, Zanker KS, Entschladen F (2001) Norepinephrine-induced migration of SW 480 colon carcinoma cells is inhibited by beta-blockers. Cancer Res

69. Yang EV, Bane CM, MacCallum RC et al (2002) Stress-related modulation of matrix metalloproteinase expression. J Neuroimmunol. https://doi.org/10.1016/S0165-5728(02)00270-9

70. Lang K, Drell TL, Lindecke A et al (2004) Induction of a metastatogenic tumor cell type by neurotransmitters and its pharmacological inhibition by established drugs. Int J Cancer. https:// doi.org/10.1002/ijc.20410

71. Drell TL IV, Joseph J, Lang K et al (2003) Effects of neurotransmitters on the chemokinesis and chemotaxis of MDA-MB-468 human breast carcinoma cells. Breast Cancer Res Treat. https:// doi.org/10.1023/A:1024491219366

72. Sloan EK, Priceman SJ, Cox BF et al (2010) The sympathetic nervous system induces a metastatic switch in primary breast cancer. Cancer Res. https://doi.org/10.1158/0008-5472.CAN-100522

73. Thayer JF, Sternberg E (2006) Beyond heart rate variability: vagal regulation of allostatic systems. In: Annals of the New York Academy of Sciences

74. Kamiya A, Hayama Y, Kato S et al (2019) Genetic manipulation of autonomic nerve fiber innervation and activity and its effect on breast cancer progression. Nat Neurosci. https://doi.org/10.1038/ s41593-019-0430-3

75. Thayer JF, Lane RD (2007) The role of vagal function in the risk for cardiovascular disease and mortality. Biol Psychol. https://doi. org/10.1016/j.biopsycho.2005.11.013

76. Bower JE, Ganz PA, Aziz N et al (2007) Inflammatory responses to psychological stress in fatigued breast cancer survivors: relationship to glucocorticoids. Brain Behav Immun. https://doi.org/ 10.1016/j.bbi.2006.08.001

77. Complementary and Alternative Medicine. In: 2017. https://nccih. nih.gov/news/camstats/2010/introduction.htm. Accessed 7 Jul 2019

78. (2017) National Center of Complementary and Alternative Medicine - A Special Report. https://nccih.nih.gov/sites/nccam. nih.gov/files/NCCAM_Special_Report.pdf. Accessed 7 Jul 2019

79. Boon HS, Olatunde F, Z Zick SM (2007) Trends in complementary/ alternative medicine use by breast cancer survivors: comparing survey data from 1998 and 2005. BMC Womens Health. https:// doi.org/10.1186/1472-6874-7-4

80. Tautz E, Momm F, Hasenburg A, Guethlin C (2012) Use of complementary and alternative medicine in breast cancer patients and their experiences: a cross-sectional study. Eur J Cancer. https:// doi.org/10.1016/j.ejca.2012.04.021

81. Greenlee H, Kwan ML, Ergas IJ et al (2009) Complementary and alternative therapy use before and after breast cancer diagnosis: the Pathways Study. Breast Cancer Res Treat 117:653-665. https://doi.org/10.1007/s10549-009-0315-3

82. Molassiotis A, Scott JA, Kearney N et al (2006) Complementary and alternative medicine use in breast cancer patients in Europe. Support Care Cancer. https://doi.org/10.1007/s00520-005-0883-7

83. Henderson JW, Donatelle RJ (2004) Complementary and alternative medicine use by women after completion of allopathic treatment for breast cancer. Altern Ther Health Med

84. Wanchai A, Armer JM, Stewart BR (2010) Complementary and alternative medicine use among women with breast cancer: a systematic review. Clin J Oncol Nurs

85. Pedersen CG, Christensen S, Jensen AB, Zachariae R (2013) In God and CAM we trust. Religious faith and use of complementary 
and alternative medicine (CAM) in a nationwide cohort of women treated for early breast cancer. J Relig Health. https://doi.org/10. 1007/s10943-012-9569-x

86. Listing M, Krohn M, Liezmann C et al (2010) The efficacy of classical massage on stress perception and cortisol following primary treatment of breast cancer. Arch Womens Ment Health. https://doi.org/10.1007/s00737-009-0143-9

87. Kabat-Zinn J (1990) Full catastrophe living: The program of the Stress Reduction Clinic at the University of Massachusetts Medical Center

88. Carlson LE (2016) Mindfulness-based interventions for coping with cancer. Ann N Y Acad Sci. https://doi.org/10.1111/nyas. 13029

89. Carlson L (2017) Mindfulness and cancer care: easing emotional and physical suffering. Altern Complement Ther

90. Carlson LE, Zelinski E, Toivonen K et al (2017) Mind-body therapies in cancer: what is the latest evidence? Curr Oncol Rep

91. Carlson LE, Speca M, Faris P, Patel KD (2007) One year pre-post intervention follow-up of psychological, immune, endocrine and blood pressure outcomes of mindfulness-based stress reduction (MBSR) in breast and prostate cancer outpatients. Brain Behav Immun. https://doi.org/10.1016/j.bbi.2007.04.002

92. Zainal NZ, Booth S, Huppert FA (2013) The efficacy of mindfulness-based stress reduction on mental health of breast cancer patients: a meta-analysis. Psychooncology

93. Haller H, Winkler MM, Klose P et al (2017) Mindfulness-based interventions for women with breast cancer: an updated systematic review and meta-analysis. Acta Oncol (Madr)

94. Piet J, Würtzen H, Zachariae R (2012) The effect of mindfulnessbased therapy on symptoms of anxiety and depression in adult cancer patients and survivors: a systematic review and meta-analysis. J Consult Clin Psychol

95. Schellekens MPJ, Tamagawa R, Labelle LE et al (2017) Mindfulness-based cancer recovery (MBCR) versus supportive expressive group therapy (SET) for distressed breast cancer survivors: evaluating mindfulness and social support as mediators. J Behav Med. https://doi.org/10.1007/s10865-016-9799-6

96. Carlson LE, Beattie TL, Giese-Davis J et al (2015) Mindfulnessbased cancer recovery and supportive-expressive therapy maintain telomere length relative to controls in distressed breast cancer survivors. Cancer. https://doi.org/10.1002/cncr.29063

97. Speca M, Carlson LE, Goodey E, Angen M (2000) A randomized, wait-list controlled clinical trial: the effect of a mindfulness meditation-based stress reduction program on mood and symptoms of stress in cancer outpatients. Psychosom Med. https://doi. org/10.1097/00006842-200009000-00004

98. Schellekens MPJ, van den Hurk DGM, Prins JB et al (2017) Mindfulness-based stress reduction added to care as usual for lung cancer patients and/or their partners: a multicentre randomized controlled trial. Psychooncology. https://doi.org/10.1002/pon. 4430

99. Banerjee B, Vadiraj HS, Ram A et al (2007) Effects of an integrated yoga program in modulating psychological stress and radiation-induced genotoxic stress in breast cancer patients undergoing radiotherapy. Integr Cancer Ther. https://doi.org/10.1177/ 1534735407306214

100. Lin K-Y, Hu Y-T, Chang K-J et al (2011) Effects of yoga on psychological health, quality of life, and physical health of patients with cancer: a meta-analysis. Evidence-Based Complement Altern Med. https://doi.org/10.1155/2011/659876

101. Moadel AB, Shah C, Wylie-Rosett J et al (2007) Randomized controlled trial of yoga among a multiethnic sample of breast cancer patients: effects on quality of life. J Clin Oncol. https:// doi.org/10.1200/JCO.2006.06.6027

102. Rao RM, Nagendra HR, Raghuram $N$ et al (2008) Influence of yoga on mood states, distress, quality of life and immune outcomes in early stage breast cancer patients undergoing surgery. Int J Yoga. https://doi.org/10.4103/0973-6131.36795

103. Rao MR, Raghuram N, Nagendra HR et al (2009) Anxiolytic effects of a yoga program in early breast cancer patients undergoing conventional treatment: a randomized controlled trial. Complement Ther Med. https://doi.org/10.1016/j.ctim.2008.05. 005

104. Carson JW, Carson KM, Porter LS et al (2009) Yoga of awareness program for menopausal symptoms in breast cancer survivors: results from a randomized trial. Support Care Cancer. https://doi. org/10.1007/s00520-009-0587-5

105. Bower JE, Garet D, Sternlieb B et al (2012) Yoga for persistent fatigue in breast cancer survivors: a randomized controlled trial. Cancer. https://doi.org/10.1002/cncr.26702

106. Chandwani KD, Thornton B, Perkins GH et al (2010) Yoga improves quality of life and benefit finding in women undergoing radiotherapy for breast cancer. J Soc Integr Oncol

107. Culos-Reed SN, Carlson LE, Daroux LM, Hately-Aldous S (2006) A pilot study of yoga for breast cancer survivors: physical and psychological benefits. Psychooncology. https://doi.org/10. 1002/pon.1021

108. Danhauer SC, Mihalko SL, Russell GB et al (2009) Restorative yoga for women with breast cancer: finding from a randomized pilot study. Psychooncology. https://doi.org/10.1002/pon.1503

109. Kovacic T, Kovacic M (2011) Impact of relaxation training according to Yoga In Daily Life system on self-esteem after breast cancer surgery. J Altern Complement Med. https://doi.org/10. 1089/acm.2010.0653

110. Lengacher CA, Reich RR, Post-White J et al (2012) Mindfulness based stress reduction in post-treatment breast cancer patients: an examination of symptoms and symptom clusters. J Behav Med. https://doi.org/10.1007/s10865-011-9346-4

111. Littman AJ, Bertram LC, Ceballos R et al (2012) Randomized controlled pilot trial of yoga in overweight and obese breast cancer survivors: effects on quality of life and anthropometric measures. Support Care Cancer. https://doi.org/10.1007/s00520-010-1066-8

112. Pavão TS, Vianna P, Pillat MM et al (2010) Acupuncture is effective to attenuate stress and stimulate lymphocyte proliferation in the elderly. Neurosci Lett. https://doi.org/10.1016/j.neulet.2010. 08.016

113. Mori H, Kuge H, Tanaka TH et al (2013) Effects of acupuncture treatment on natural killer cell activity, pulse rate, and pain reduction for older adults: an uncontrolled, observational study. J Chinese Integr Med. https://doi.org/10.3736/jintegrmed2013012

114. Carlos Lopes-Júnior L, Cruz LAP da, Leopoldo VC, et al (2016) Effectiveness of traditional Chinese acupuncture versus sham acupuncture: a systematic review. Rev Lat Am Enfermagem https:// doi.org/10.1590/1518-8345.0647.2762

115. Johnston MF, Ortiz SÃnchez E, Vujanovic NL, Li W (2011) Acupuncture may stimulate anticancer immunity via activation of natural killer cells. Evidence-based Complement Altern Med

116. Abrahão CA, Bomfim E, Lopes-Júnior LC, Pereira-da-Silva G (2019) Complementary therapies as a strategy to reduce stress and stimulate immunity of women with breast cancer. J Evidence-Based Integr Med. https://doi.org/10.1177/ 2515690X19834169

117. Chien TJ, Hsu CH, Liu CY, Fang CJ (2017) Effect of acupuncture on hot flush and menopause symptoms in breast cancer - a systematic review and meta-analysis. PLoS One. https://doi.org/10. 1371/journal.pone.0180918

118. Freedman RR (2005) Pathophysiology and treatment of menopausal hot flashes. Semin Reprod Med 23:117-125. https://doi. org $/ 10.1055 / \mathrm{s}-2005-869479$

119. O'Regan D, Filshie J (2010) Acupuncture and cancer. Auton Neurosci Basic Clin. https://doi.org/10.1016/j.autneu.2010.05. 001 
120. de Valois BA, Young TE, Robinson N et al (2010) Using traditional acupuncture for breast cancer-related hot flashes and night sweats. J Altern Complement Med. https://doi.org/10.1089/acm. 2009.0472

121. Walker EM, Rodriguez AI, Kohn B et al (2010) Acupuncture versus venlafaxine for the management of vasomotor symptoms in patients with hormone receptor-positive breast cancer: a randomized controlled trial. J Clin Oncol. https://doi.org/10.1200/ JCO.2009.23.5150

122. Ernst E (2006) Herbal remedies for anxiety - a systematic review of controlled clinical trials. Phytomedicine

123. Saeed SA, Bloch RM, Antonacci DJ (2007) Herbal and dietary supplements for treatment of anxiety disorders. Am Fam Physician

124. Naing A, Stephen SK, Frenkel M et al (2011) Prevalence of complementary medicine use in a phase 1 clinical trials program: the MD Anderson Cancer Center experience. Cancer. https://doi.org/ $10.1002 /$ cncr.26164

125. Richardson MA, Sanders T, Palmer JL et al (2000) Complementary/alternative medicine use in a comprehensive cancer center and the implications for oncology. J Clin Oncol. https://doi.org/10.1200/JCO.2000.18.13.2505

126. Navo MA, Phan J, Vaughan C et al (2004) An assessment of the utilization of complementary and alternative medication in women with gynecologic or breast malignancies. J Clin Oncol. https://doi. org/10.1200/JCO.2004.04.162

127. Lopresti AL, Smith SJ, Malvi H, Kodgule R (2019) An investigation into the stress-relieving and pharmacological actions of an ashwagandha (Withania somnifera) extract: a randomized, double-blind, placebo-controlled study. Medicine (Baltimore) 98: e17186. https://doi.org/10.1097/MD.0000000000017186

128. Palliyaguru DL, Singh SV, Kensler TW (2016) Withania somnifera: from prevention to treatment of cancer. Mol Nutr Food Res 60:1342-1353. https://doi.org/10.1002/mnfr. 201500756

129. Chandrasekhar K, Kapoor J, Anishetty S (2012) A prospective, randomized double-blind, placebo-controlled study of safety and efficacy of a high-concentration full-spectrum extract of ashwagandha root in reducing stress and anxiety in adults. Indian J Psychol Med 34:255-262. https://doi.org/10.4103/02537176.106022

130. Biswal BM, Sulaiman SA, Ismail HC et al (2013) Effect of Withania somnifera (Ashwagandha) on the development of chemotherapy-induced fatigue and quality of life in breast cancer patients. Integr Cancer Ther 12:312-322. https://doi.org/10.1177/ 1534735412464551

131. Qi F, Li A, Inagaki Y et al (2010) Chinese herbal medicines as adjuvant treatment during chemoor radio-therapy for cancer. Biosci Trends

132. Alpert JE, Mischoulon D, Rubenstein GEF et al (2002) Folinic acid (leucovorin) as an adjunctive treatment for SSRI-refractory depression. Ann Clin Psychiatry. https://doi.org/10.1023/A: 1015271927517

133. Coppen A, Bailey J (2000) Enhancement of the antidepressant action of fluoxetine by folic acid: a randomised, placebo controlled trial. J Affect Disord. https://doi.org/10.1016/S01650327(00)00153-1

134. Almeida OP, McCaul K, Hankey GJ et al (2008) Homocysteine and depression in later life. Arch Gen Psychiatry. https://doi.org/ 10.1001/archpsyc.65.11.1286

135. Carney MWP, Chary TKN, Laundy M et al (1990) Red cell folate concentrations in psychiatric patients. J Affect Disord. https://doi. org/10.1016/0165-0327(90)90093-N

136. Coppen A, Abou-Saleh MT (1982) Plasma folate and affective morbidity during long-term lithium therapy. Br J Psychiatry. https://doi.org/10.1192/bjp.141.1.87
137. Lawenda BD, Kelly KM, Ladas EJ et al (2008) Should supplemental antioxidant administration be avoided during chemotherapy and radiation therapy? J Natl Cancer Inst

138. Yarney J, Donkor A, Opoku SY et al (2013) Characteristics of users and implications for the use of complementary and alternative medicine in Ghanaian cancer patients undergoing radiotherapy and chemotherapy: a cross-sectional study. BMC Complement Altern Med. https://doi.org/10.1186/1472-6882-13-16

139. Ambrosone CB, Zirpoli GR, Hutson AD et al (2019) Dietary supplement use during chemotherapy and survival outcomes of patients with breast cancer enrolled in a cooperative group clinical trial (SWOG S0221). J Clin Oncol:JCO1901203. https://doi.org/ 10.1200/JCO.19.01203

140. Richards MA, Westcombe AM, Love SB et al (1999) Influence of delay on survival in patients with breast cancer: a systematic review. Lancet (London, England) 353:1119-1126. https://doi.org/ 10.1016/s0140-6736(99)02143-1

141. Spiegel D, Bloom JR, Yalom I (1981) Group support for patients with metastatic cancer. A randomized outcome study. Arch Gen Psychiatry 38:527-533. https://doi.org/10.1001/archpsyc.1980. 01780300039004

142. Spiegel D, Bloom JR (1983) Group therapy and hypnosis reduce metastatic breast carcinoma pain. Psychosom Med 45:333-339. https://doi.org/10.1097/00006842-198308000-00007

143. Cunningham AJ, Edmonds CV, Jenkins GP et al A randomized controlled trial of the effects of group psychological therapy on survival in women with metastatic breast cancer. Psychooncology 7:508-517. https://doi.org/10.1002/(SICI)1099-1611(199811/12) 7:6<508::AID-PON376>3.0.CO;2-7

144. Edmonds CV, Lockwood GA, Cunningham AJ Psychological response to long-term group therapy: a randomized trial with metastatic breast cancer patients. Psychooncology 8:74-91. https:// doi.org/10.1002/(SICI)1099-1611(199901/02)8:1<74::AIDPON339>3.0.CO;2-K

145. Fawzy FI, Fawzy NW, Hyun CS et al (1993) Malignant melanoma. Effects of an early structured psychiatric intervention, coping, and affective state on recurrence and survival 6 years later. Arch Gen Psychiatry 50:681-689. https://doi.org/10.1001/archpsyc. 1993.01820210015002

146. Kuchler T, Henne-Bruns D, Rappat S et al Impact of psychotherapeutic support on gastrointestinal cancer patients undergoing surgery: survival results of a trial. Hepatogastroenterology 46:322335

147. Kim SH, Shin MS, Lee HS et al (2011) Randomized pilot test of a simultaneous stage-matched exercise and diet intervention for breast cancer survivors. Oncol Nurs Forum 38:E97-E106. https://doi.org/10.1188/11.ONF.E97-E106

148. Gnagnarella $\mathrm{P}$, Dragà $\mathrm{D}$, Baggi $\mathrm{F}$ et al (2016) Promoting weight loss through diet and exercise in overweight or obese breast cancer survivors (InForma): study protocol for a randomized controlled trial. Trials. https://doi.org/10.1186/s13063-016-1487-x

149. Badger T, Segrin C, Pasvogel A, Lopez AM (2013) The effect of psychosocial interventions delivered by telephone and videophone on quality of life in early-stage breast cancer survivors and their supportive partners. J Telemed Telecare. https://doi.org/10.1177/ 1357633 X13492289

150. Badger T, Segrin C, Meek P et al (2004) A case study of telephone interpersonal counseling for women with breast cancer and their partners. Oncol Nurs Forum. https://doi.org/10.1188/04.ONF. 997-1003

151. Midtgaard J, Rørth M, Stelter R et al (2005) The impact of a multidimensional exercise program on self-reported anxiety and depression in cancer patients undergoing chemotherapy: a phase II study. Palliat Support Care. https://doi.org/10.1017/ s1478951505050327 
152. Yang CY, Tsai JC, Huang YC, Lin CC (2011) Effects of a homebased walking program on perceived symptom and mood status in postoperative breast cancer women receiving adjuvant chemotherapy. J Adv Nurs. https://doi.org/10.1111/j.1365-2648.2010. 05492.x

153. Mock V, Pickett M, Ropka ME et al (2001) Fatigue and quality of life outcomes of exercise during cancer treatment. Cancer Pract. https://doi.org/10.1046/j.1523-5394.2001.009003119.x

154. LaVoy ECP, Fagundes CP, Dantzer R (2016) Exercise, inflammation, and fatigue in cancer survivors. Exerc Immunol Rev

155. Segerstrom SC, Nes LS (2007) Heart rate variability reflects selfregulatory strength, effort, and fatigue. Psychol Sci. https://doi. org/10.1111/j.1467-9280.2007.01888.x

156. Crosswell AD, Lockwood KG, Ganz PA, Bower JE (2014) Low heart rate variability and cancer-related fatigue in breast cancer survivors. Psychoneuroendocrinology. https://doi.org/10.1016/j. psyneuen.2014.03.011

157. Vigo C, Gatzemeier W, Sala R et al (2015) Evidence of altered autonomic cardiac regulation in breast cancer survivors. J Cancer Surviv. https://doi.org/10.1007/s11764-015-0445-z

158. Fagundes CP, Murray DM, Hwang BS et al (2011) Sympathetic and parasympathetic activity in cancer-related fatigue: more evidence for a physiological substrate in cancer survivors. Psychoneuroendocrinology. https://doi.org/10.1016/j.psyneuen. 2011.02.005

159. Levy WC, Cerqueira MD, Harp GD et al (1998) Effect of endurance exercise training on heart rate variability at rest in healthy young and older men. Am J Cardiol. https://doi.org/10.1016/ S0002-9149(98)00611-0

160. Seals DR, Chase PB (1989) Influence of physical training on heart rate variability and baroreflex circulatory control. J Appl Physiol. https://doi.org/10.1152/jappl.1989.66.4.1886

161. Nolan RP, Jong P, Barry-Bianchi SM et al (2008) Effects of drug, biobehavioral and exercise therapies on heart rate variability in coronary artery disease: a systematic review. Eur J Prev Cardiol

162. Niederer D, Vogt L, Thiel C et al (2013) Exercise effects on HRV in cancer patients. Int J Sports Med. https://doi.org/10.1055/s$0032-1314816$

163. Wennerberg E, Lhuillier C, Rybstein MD et al (2020) Exercise reduces immune suppression and breast cancer progression in a preclinical model. Oncotarget 11:452-461. https://doi.org/10. 18632/oncotarget. 27464

164. Schmidt T, van Mackelenbergh M, Wesch D, Mundhenke C Physical activity influences the immune system of breast cancer patients. J Cancer Res Ther 13:392-398. https://doi.org/10.4103/ 0973-1482.150356

165. Hayes SC, Steele ML, Spence RR et al (2018) Exercise following breast cancer: exploratory survival analyses of two randomised, controlled trials. Breast Cancer Res Treat. https://doi.org/10.1007/ s10549-017-4541-9

166. Ibrahim EM, Al-Homaidh A (2011) Physical activity and survival after breast cancer diagnosis: meta-analysis of published studies. Med Oncol

167. Courneya KS, Segal RJ, McKenzie DC et al (2014) Effects of exercise during adjuvant chemotherapy on breast cancer outcomes. Med Sci Sports Exerc. https://doi.org/10.1249/MSS. 0000000000000297

168. Cannioto RA, Dighe S, Mahoney MC et al (2019) Habitual recreational physical activity is associated with significantly improved survival in cancer patients: evidence from the Roswell Park Data Bank and BioRepository. Cancer Causes Control. https://doi.org/ 10.1007/s10552-018-1101-5

169. Cannioto RA, Hutson A, Dighe S, McCann W, McCann SE, Zirpoli GR, Barlow W, Kelly KM, DeNysschen CA, Hershman DL, Unger JM (2020) Physical activity before, during and after chemotherapy for high-risk breast cancer: relationships with survival. J Natl Cancer Inst

170. Obradović MMS, Hamelin B, Manevski N et al (2019) Glucocorticoids promote breast cancer metastasis. Nature 567: 540-544. https://doi.org/10.1038/s41586-019-1019-4

171. Schmid P, Adams S, Rugo HS et al (2018) Atezolizumab and Nab-paclitaxel in advanced triple-negative breast cancer. N Engl J Med 379:2108-2121. https://doi.org/10.1056/NEJMoa1809615

172. Conzen SD (2017) Recent advances in understanding glucocorticoid receptor function in cancer. Clin Adv Hematol Oncol 15: 338-340

173. Gandhi S, Elkhanany A, Oshi M et al (2020) Contribution of immune cells to glucocorticoid receptor expression in breast cancer. Int J Mol Sci 21. https://doi.org/10.3390/ijms21134635

174. West DC, Kocherginsky M, Tonsing-Carter EY et al (2018) Discovery of a glucocorticoid receptor (GR) activity signature using selective GR antagonism in ER-negative breast cancer. Clin Cancer Res 24:3433-3446. https://doi.org/10.1158/10780432.CCR-17-2793

175. Skor MN, Wonder EL, Kocherginsky M et al (2013) Glucocorticoid receptor antagonism as a novel therapy for triple-negative breast cancer. Clin Cancer Res 19:6163-6172. https://doi.org/10.1158/1078-0432.CCR-12-3826

176. Benish M, Bartal I, Goldfarb Y et al (2008) Perioperative use of $\beta$ blockers and COX-2 inhibitors may improve immune competence and reduce the risk of tumor metastasis. Ann Surg Oncol. https:// doi.org/10.1245/s10434-008-9890-5

177. Zhang D, Ma QY, Hu HT, Zhang M (2010) $\beta 2$-adrenergic antagonists suppress pancreatic cancer cell invasion by inhibiting CREB, NFKB and AP-1. Cancer Biol Ther. https://doi.org/10. 4161/cbt.10.1.11944

178. Dhabhar FS (2014) Effects of stress on immune function: the good, the bad, and the beautiful. Immunol Res

179. Antoni MH, Dhabhar FS (2019) The impact of psychosocial stress and stress management on immune responses in patients with cancer. Cancer

180. Hylander BL, Gordon CJ, Repasky EA (2019) Manipulation of ambient housing temperature to study the impact of chronic stress on immunity and cancer in mice. J Immunol 202:631-636. https:// doi.org/10.4049/jimmunol.1800621

181. Thaker PH, Han LY, Kamat AA et al (2006) Chronic stress promotes tumor growth and angiogenesis in a mouse model of ovarian carcinoma. Nat Med 12:939-944. https://doi.org/10.1038/ nm1447

182. Choy C, Raytis JL, Smith DD et al (2016) Inhibition of $\beta 2-$ adrenergic receptor reduces triple-negative breast cancer brain metastases: the potential benefit of perioperative $\beta$-blockade. Oncol Rep. https://doi.org/10.3892/or.2016.4710

183. Chen H, Liu D, Guo L et al (2018) Chronic psychological stress promotes lung metastatic colonization of circulating breast cancer cells by decorating a pre-metastatic niche through activating $\beta$ adrenergic signaling. J Pathol 244:49-60. https://doi.org/10.1002/ path.4988

184. Nagaraja AS, Dood RL, Armaiz-Pena G et al (2017) Adrenergicmediated increases in INHBA drive CAF phenotype and collagens. JCI Insight. https://doi.org/10.1172/jci.insight.93076

185. Lamkin DM, Ho HY, Ong TH et al (2016) $\beta$-Adrenergicstimulated macrophages: comprehensive localization in the M1M2 spectrum. Brain Behav Immun. https://doi.org/10.1016/j.bbi. 2016.07.162

186. Cremaschi GA, Fisher P, Boege F Beta-adrenoceptor distribution in murine lymphoid cell lines. Immunopharmacology 22:195206. https://doi.org/10.1016/0162-3109(91)90044-y

187. Barron TI, Connolly RM, Sharp L et al (2011) Beta blockers and breast cancer mortality: a population-based study. J Clin Oncol. https://doi.org/10.1200/JCO.2010.33.5422 
188. Montoya A, Amaya CN, Belmont A et al (2017) Use of nonselective \&\#x3B2;-blockers is associated with decreased tumor proliferative indices in early stage breast cancer. Oncotarget. https://doi.org/10.18632/oncotarget.14119

189. Zhou L, Li Y, Li X et al (2016) Propranolol attenuates surgical stress-induced elevation of the regulatory $\mathrm{T}$ cell response in patients undergoing radical mastectomy. J Immunol. https://doi.org/ 10.4049/jimmunol.1501677

190. Hiller JG, Cole SW, Crone EM et al (2020) Preoperative $\beta$ blockade with propranolol reduces biomarkers of metastasis in breast cancer: a phase II randomized trial. Clin Cancer Res 26: 1803-1811. https://doi.org/10.1158/1078-0432.CCR-19-2641

191. Botteri E, Munzone E, Rotmensz N et al (2013) Therapeutic effect of $\beta$-blockers in triple-negative breast cancer postmenopausal women. Breast Cancer Res Treat. https://doi.org/10.1007/ s10549-013-2654-3

192. Liu D, Yang Z, Wang T et al (2016) $\beta 2$-AR signaling controls trastuzumab resistance-dependent pathway. Oncogene 35:47-58. https://doi.org/10.1038/onc.2015.58

193. Ganz PA, Habel LA, Weltzien EK et al (2011) Examining the influence of beta blockers and ACE inhibitors on the risk for breast cancer recurrence: results from the LACE cohort. Breast Cancer Res Treat. https://doi.org/10.1007/s10549-011-1505-3
194. Melhem-Bertrandt A, Chavez-MacGregor M, Lei X et al (2011) Beta-blocker use is associated with improved relapse-free survival in patients with triple-negative breast cancer. J Clin Oncol. https:// doi.org/10.1200/JCO.2010.33.4441

195. (2010) Beta-blocker drug therapy reduces secondary cancer formation in breast cancer and improves cancer specific survival. Oncotarget. https://doi.org/10.18632/oncotarget.197

196. Qinye F, Zhigang Y, Dezong G, Zhongbing M (2015) Carvedilol suppresses migration and invasion of malignant breast cells by inactivating Src involving cAMP/PKA and $\mathrm{PKC} \delta$ signaling pathway. J Cancer Res Ther. https://doi.org/10.4103/0973-1482. 137664

197. Pasquier E, Street J, Pouchy C et al (2013) B-blockers increase response to chemotherapy via direct antitumour and antiangiogenic mechanisms in neuroblastoma. Br J Cancer. https:// doi.org/10.1038/bjc.2013.205

198. Talarico G, Orecchioni S, Dallaglio K et al (2016) Aspirin and atenolol enhance metformin activity against breast cancer by targeting both neoplastic and microenvironment cells. Sci Rep. https://doi.org/10.1038/srep18673

Publisher's note Springer Nature remains neutral with regard to jurisdictional claims in published maps and institutional affiliations. 